\title{
Effect of Chemicals Treatment on Keeping Quality and Vase Life of Gladiolus Flowers
}

\author{
Naser Khan Mohibe ${ }^{1}$, S. K. Jain ${ }^{2}$, Ashutosh Mishra ${ }^{3}$, Nirmal Meena ${ }^{4}$
}

\begin{abstract}
Gladiolus is one of the most common cut flowers and has the highest economic importance in the floriculture industry. Vase life differs among various species and cultivars. It is one of the most valuable characteristics for determining flower quality, satisfying consumer preferences and prolonging its commercial value. Maintenance of optimal water status is the most important factor for enhancing vase life period. Results indicate that maximum per cent change in fresh weight by spike at senescence stage, maximum diameter of basal floret, maximum per cent change in length by spike at senescence stage, highest water uptake, longest longevity of floret, highest number of opened florets per spike at a time and longest vase life were significantly recorded in treatment sucrose $(5 \%)$ + salicylic acid $150 \mathrm{ppm}$ as compared to control. Among all the used chemicals concentration 150 ppm SA vase solution found most feasible for keeping quality and long vase life. SA play an important role in regulating a number of physiological processes and provide protection against biotic and abiotic stresses in plant by regulating plant growth and development process such as ethylene biosynthesis, stomatal conductance, respiration and activation of defense systems against different pathogens.
\end{abstract}

Key words: Gladiolus, salicylic acid, post harvest quality, vase life.

\section{INTRODUCTION}

Gladiolus flower is a spike inflorescence and normally harvested with relatively few open florets, and the life of the flower depends on the life and opening of individual florets remaining on the spike which needed water absorption to continue until the end (Mirdehghan and Aghamolayi, 2016). Gladiolus is a popular cut flower in the world, but flowers longevity is very short. The vase life of individual florets is 4 to 6 days (Mayak et al., 1973). The life of the flower is a function both of the life of individual florets, the postharvest expansion and opening of the buds remaining on the spike (Serek et al., 1994). Short postharvest vase life is one of the most important problems of the cut flowers. However, longevity of vase life is an important factor in consumer preference (Da Silva, 2003). Vase life of cut flowers is mainly affected by two main factors, namely ethylene which accelerates the senescence of many flowers and microorganisms which cause vascular blockage and thus reduce the amount of water uptake, consequently the vase life of cut flowers could be reduced (Zencirkiran, 2010).The previous studies showed that exogenous ethylene and also ethylene inhibitors have no effect on petal senescence of gladiolus (Ezhilmathi et al., 2007). So, an alternative system must exist to regulate senescence in gladiolus.

Sucrose act as a source of nutrition for tissues approaching carbohydrate starvation and also act as an osmotically active molecule, thereby having a role in subsequent water relations (Kuiper et al., 1995). Hence, the use of sucrose as pulsing solutions would be of practical significance in prolonging the vase life of cut flowers and foliage (Cameron and Ride, 2001). Keeping the flowers in vase solutions containing sucrose has been shown to extend their vase-life (Yamane et al., 2005).

Tap water is mostly used as a vase solution; however, its composition also affects the efficacy of chemical solutions being made from it, including pulsing, holding and bud opening solutions (Brecheisen et al., 1995). The longevity of cut flowers is greatly affected by vase water composition, which is one of the major challenges for florists today (Ahmad et al., 2013a).

1 Research Scholar, Department of Post Harvest Technology, CHF, Jhalawar, Agriculture University Kota, Rajasthan, India-326 023.

${ }^{2}$ (Corresponding Author) Professor \& HRD Director, Department of Post

Harvest Technology Agriculture University Kota, Rajasthan, India-326 023.

E-mail: jain_shashi_kumar@yahoo.co.in Mobile No.-+91 9414782564

${ }^{3}$ Professor \& Head, Department of Floriculture and Landscaping,

Agriculture University Kota, Rajasthan, India-326 023.

${ }^{4}$ Assistant Professor, Department of Fruit Science, CHF, Jhalawar,

Agriculture University Kota, Rajasthan, India-326 023.

Received, June 2, 2020, Accepted, , June 30, 2020. 
Salicylic acid (SA) is an endogenous growth regulator of phenolic nature and considered as a hormone like substance which plays an important role in regulating a number of physiological processes and provide protection against biotic and abiotic stresses in plant by regulating plant growth and development such as: ethylene biosynthesis, stomatal conductance, respiration and defense in different types of plants (Loutfy et al., 2012). SA has a vital role in plant defense and is implicated in the activation of defense systems against different pathogens (Grant and Lamb, 2006 and Miura et al., 2010). Dumitras et al. (2002) stated that SA increased vase life of gerbera and gladiolus flowers.

Essential oil (E.O) is natural and environmental friendly used in floriculture to enhance the vase of cut flowers due to their antimicrobial property (Burt et al., 2004) and increasing vase life of cut flowers and mainly extracted from aromatic plants like savory, ajowan, geranium, mint, Artemisia, eucalyptus, and coriander. The active compound responsible for antimicrobial property is terpenes (Tian et al., 2011). In many studies it is found that essential oil give positive and beneficial result like in gerbera, chrysanthemum, rose, carnation, gladiolus and alstroemeria and in many other cut flowers (Prabha et al., 2018).

5-sulfosalicylic acid is the salicylic acid (SA) driven compound with sulfur group which may act more effective than SA because of its probable antimicrobial effect. SA can prevent ACC-oxidase and extend the vase life of cut flowers by decreasing reactive oxygen species (ROS) and ethylene (Zamani et al., 2011).

Therefore, the present experiment was designed mainly to evaluate suitable vase solution for flowers of gladioulus and to test chemical preservatives as holding solution and identify the best biocide solution combination with sucrose to extend the vase life of gladiolus cut flowers to find out the response of cut chrysanthemum flowers to some preservative solutions.

\section{MATERIALS AND METHODS}

Experimental site: This study was conducted at the Postharvest Laboratory of College of Horticulture and Forestry, Jhalawar, Agricultural University Kota, Rajasthan in month of November, 2018 to March, 2019 to find out the response of cut gladiolus flowers to some preservative solutions.

Plant material: Cut flower stems of gladiolus were freshly obtained from gladiolus var. American Beauty plant which were grown at the instructional farm, Department of Floriculture and Landscaping, College of Horticulture and Forestry, Jhalawar. The spikes having 5-9 basal buds and show colour were picked in the early morning and directly wrapped in groups and quickly transported to the laboratory within 1 hour. As soon as in the lab, stems were firstly pre-cooled by placing in cold water for half an hour to remove the effect of high field heat. Thereafter, stem bases were recut under water to avoid air embolism. Stems were adjusted to the same length $(25 \mathrm{~cm})$ and shape. Injury free gladiolus stems were selected for the experiment.

\begin{tabular}{cccc} 
Chemical analysis of tap water $(\mathbf{m e q} / \mathbf{l})$ & \\
\hline $\mathrm{pH}$ & 7.0 & $\mathrm{Ca}^{++}$ & 1.3 \\
$\mathrm{EC}(\mathrm{dS} / \mathrm{m})$ & 0.42 & $\mathrm{Mg}^{++}$ & 0.9 \\
$\mathrm{Cl}^{-}$ & 2.2 & $\mathrm{Na}^{+}$ & 2.1 \\
$\mathrm{SO}_{4}$ & 1.0 & $\mathrm{~K}^{+}$ & 1.0 \\
\hline
\end{tabular}

Experimental design and treatments: Five treatments were arranged in a completely randomized design with 3 replications. Stems of flowers were placed in conical flask $(1000 \mathrm{ml})$ containing $500 \mathrm{ml}$ of holding solutions at different concentration of salicylic acid. The mouth of each conical flask was covered with muslin cloth to prevent evaporation and microbial growth. Tap water was used in the preparation the holding solution and this solution was not changed or substituted throughout the experiment.

The spikes were harvested early in the morning at showing color stage of the three basal florets, then they were quickly brought to the laboratory on 12/01/2019 to 31/01/2019 for the experiment. All spike stems were trimmed to have an average spike length of $25 \mathrm{~cm}$ and 5-9 flower buds/spike. Mean temperature was $19{ }^{\circ} \mathrm{C}( \pm$ $2{ }^{\circ} \mathrm{C}$ ) for the whole experiment. While the averages of the relative humidity were $25 \%$ during the experiment. The average of the light intensity for the experiments was 75 lux. 
Treatment details are given below:

\begin{tabular}{|c|c|}
\hline Treatment & Treatment Details \\
\hline $\mathrm{T}_{0}$ & Tap water (Control) \\
\hline $\mathrm{T}_{1}$ & Sucrose $(5 \%)$ \\
\hline $\mathrm{T}_{2}$ & Sucrose $(5 \%)+$ Salicylic Acid $150 \mathrm{ppm}$ \\
\hline $\mathrm{T}_{3}$ & Sucrose $(5 \%)+$ Salicylic Acid $300 \mathrm{ppm}$ \\
\hline $\mathrm{T}_{4}$ & Sucrose $(5 \%)+$ Salicylic Acid 450 ppm \\
\hline $\mathrm{T}_{5}$ & Sucrose $(5 \%)+$ Sulfosalicylic Acid $100 \mathrm{ppm}$ \\
\hline $\mathrm{T}_{6}$ & Sucrose $(5 \%)+$ Sulfosalicylic Acid $200 \mathrm{ppm}$ \\
\hline $\mathrm{T}_{7}$ & Sucrose $(5 \%)+$ Sulfosalicylic Acid $300 \mathrm{ppm}$ \\
\hline $\mathrm{T}_{8}$ & Sucrose $(5 \%)+$ Ajowan E.O. 500 ppm \\
\hline $\mathrm{T}_{9}$ & Sucrose $(5 \%)+$ Ajowan E.O. 1000 ppm \\
\hline $\mathrm{T}_{10}$ & Sucrose $(5 \%)+$ Salicylic Acid $150 \mathrm{ppm}+$ Ajowan E.O. $500 \mathrm{ppm}$ \\
\hline $\mathrm{T}_{11}$ & Sucrose (5\%) + Salicylic Acid $150 \mathrm{ppm}+$ Ajowan E.O. $1000 \mathrm{ppm}$ \\
\hline $\mathrm{T}_{12}$ & Sucrose $(5 \%)+$ Salicylic Acid 300 ppm+ Ajowan E.O. 500 ppm \\
\hline $\mathrm{T}_{13}$ & Sucrose $(5 \%)+$ Salicylic Acid 300 ppm+ Ajowan E.O. 1000 ppm \\
\hline $\mathrm{T}_{14}$ & Sucrose $(5 \%)+$ Salicylic Acid 450 ppm+ Ajowan E.O. 500 ppm \\
\hline $\mathrm{T}_{15}$ & Sucrose $(5 \%)+$ Salicylic Acid $450 \mathrm{ppm}+$ Ajowan E.O. $1000 \mathrm{ppm}$ \\
\hline
\end{tabular}

Data collected were fresh weight of spike (g), diameter of basal florets $(\mathrm{cm})$, per cent change in spike length $(\%)$, water uptake $(\mathrm{g})$, longevity of first five florets, number of opened florets/spike, per cent opened florets/spike (\%) and vase life (day) at the end of experiment using following given methods:

Water uptake (g): Difference between consecutive weights of bottles with the solution (without flower) was represent water uptake (g). Total water uptake were recorded for the entire period of vase life of the spikes.

Diameter of Basal Florets (cm): Diameter of basal floret on $1^{\text {st }}, 3^{\text {rd }}$ and fully opened stage was measured on two perpendicular axis with the help of vernier's calipers.

Longevity of basal floret: Observations on time taken from opening to fading of basal floret recorded in days and mean was calculated.

Per cent opened florets/spike: The total number of florets on each spike were counted at harvesting stage and the total number of florets opened during vase life were counted. Per cent opened florets/spike were calculated as:

Per cent opened

Florets/spike $(\%)=\frac{\text { Wumber of opened florets per spike }}{\text { Total number of florets per spike }} x 100$

Percent change in spike length (\%): The length of spike was measured from basal floret bud to the tip of spike in $\mathrm{cm}$. Length of spike was recorded on $1^{\text {st }}, 6^{\text {th }}$ day and at senescence stage. Percent change in spike length was calculated in relation to initial length on $6^{\text {th }}$ and at senescence stage.

Change in spike length (\%)

$=\frac{\text { Final spike length-initial spike length }}{\text { Final spike length }} x 100$
Statistical Design: The experiment was laid out in Completely Randomized Block Design (CRD). The recorded data for the various characters under study was analysed using F- test as suggested by Gomez and Gomez (1984) for interpretation of the results.

\section{RESULTS AND DISCUSSION}

The analysed data pertaining to keeping quality and vase life of cut gladiolus spikes are presented in the table 01 to table 03 .

\section{Water uptake by spike ( $g$ )}

Data presented in Table 1 indicated that all the used chemicals gave increases in the amount of the absorbed water by the cut gladiolus spikes, compared with the other treatment. Also, adding salicylic acid $150 \mathrm{ppm}$ with 5\% sucrose to the vase solution gave the maximum amount of water absorbed, compared with the other treatments. This treatment led to increase the amount of the absorbed vase solution with $51.9 \%$ over the control treatment. These results may be probably due to the role of salicylic acid at a proper concentration in plants. Salicylic acid protects chlorophyll (Peng et al., 2007), and protein degradation (Soobedar et al., 2015), delays the senescence of the tepals of cut gladiolus spikes (Hatamzadeh et al., 2012), enhances the relative water content of leaves (Hassan and Ali, 2014), prolongs membrane stability. All these factors probably led to increase the efficiency of the cut gladiolus spikes to absorb a large amount of the vase solution. Similar trend of results was reported by Dantuluri et al. (2008) on Gladiolus, Sardoei et al. (2013) on Narcissus and Puneet and Mukherjee (2015) on pot marigold. 


\section{Number of the fully opened floret per spike}

Data presented in Table 1 showed that all the used materials led to increase the number of the fully opened florets per spike of cut gladiolus stem, compared with the control treatment. Besides, adding sulfosalicylic acid (SA) at $150 \mathrm{ppm}$ with $5 \%$ sucrose to the holding solution gave the maximum number of the fully opened florets per spike, compared with the control treatment, which led to increase the number of the fully opened florets with $71.6 \%$ over the control treatment (Fig. 1). These results may be probably due to that using sulfosalicylic acid at a suitable concentration in vase solution led to decrease the respiration rate (Ezhilmathi et al., 2007), delay senescence (Mackay et al., 2000), activate photosynthesis rate (Senaratna et al., 2000) and increase the vase solution uptake (Alaey et al., 2011). All these attributes led to increase the cumulative synthesis materials in the cut gladiolus spikes, consequently the number of the fully opened florets per spike could be increased. Similar trend of results was reported by Rao and Ram (1982) on Gladiolus sp., ELMokadem (1991) on bird of paradise and Khattab et al. (2017) on Gladiolus grandiflorus cv. "White Prosperity".

\section{Per cent of the opened florets per spike}

Data presented in Table 1 showed that all the used chemicals with their concentrations gave significant increases in the percentage of the fully opened florets / spike, compared with the control treatment. Whereas, using sulfosalicylic acid at $150 \mathrm{ppm}$ with $5 \%$ sucrose gave the maximum percentage of the fully opened florets per spike, compared with the other treatments, which led to increase the percentage of the fully opened florets with $47.1 \%$ over the control treatment (means of the three experiments). These results may be probably due to the effect of adding sulfosalicylic acid at a suitable concentration to the holding solution on enhancing the level of photosynthetic pigments, photosynthetic rate and modification the actively of some of the important enzymes as well (Yusuf et al., 2013). Consequently, the production and accumulation of the bio-synthesis materials would be increased in the cut gladiolus spike, thus more florets could be developed and opened on the spike. Similar trend of results was reported by Ezilmathi et al. (2007) on Gladiolus flowers, Rasul et al., (2011) on Gladiolus flowers and Nasibi et al., (2014) on tuberose.

\section{Per cent change in spike length (\%)}

Data presented in Table 1 indicated that all the used chemicals gave maximum per cent change in the length of spike by gladiolus spikes, compared with the other treatment. Also, adding salicylic acid $150 \mathrm{ppm}$ with 5\% sucrose to the vase solution gave the maximum amount of water absorbed, compared with the other treatments. This treatment led to increase the amount of the absorbed vase solution with $31.6 \%$ over the control treatment. These results may be probably due to the role of salicylic acid at a proper concentration in plants. This might be due to the fact that, exogenous application of salicylic acid, which stimulated the effect of naturally occurring hormones that accelerated and modified the growth and development of plants which might have increased length of spike (Pawar et al., 2018).

Table 1.Effect of different chemicals on keeping quality and vase life of gladiolus spike

\begin{tabular}{cccccc}
\hline Treatment & $\begin{array}{c}\text { Water } \\
\text { uptake (g) }\end{array}$ & $\begin{array}{c}\text { Fully opened } \\
\text { floret (Nos.) }\end{array}$ & $\begin{array}{c}\text { Opened } \\
\text { florets/spike (\%) }\end{array}$ & $\begin{array}{c}\text { Per cent change } \\
\text { in spike length }(\boldsymbol{\%})\end{array}$ & $\begin{array}{c}\text { Vase life } \\
\text { (days) }\end{array}$ \\
\hline $\mathbf{T}_{\mathbf{0}}$ & 57.6 & 2.36 & 68 & 14.2 & 14 \\
$\mathbf{T}_{\mathbf{1}}$ & 59.4 & 3.18 & 70 & 17.2 & 15 \\
$\mathbf{T}_{\mathbf{2}}$ & 87.5 & 4.05 & 100 & 18.7 & 19 \\
$\mathbf{T}_{\mathbf{3}}$ & 61.3 & 3.87 & 100 & 14.9 & 18 \\
$\mathbf{T}_{\mathbf{4}}$ & 69.8 & 3.54 & 100 & 16.7 & 17 \\
$\mathbf{T}_{\mathbf{5}}$ & 66.0 & 3.12 & 91 & 14.4 & 16 \\
$\mathbf{T}_{\mathbf{6}}$ & 84.4 & 2.95 & 100 & 13.4 & 17 \\
$\mathbf{T}_{\mathbf{7}}$ & 67.0 & 2.87 & 100 & 13.2 & 17 \\
$\mathbf{T}_{\mathbf{8}}$ & 71.4 & 2.98 & 100 & 17.6 & 15 \\
$\mathbf{T}_{\mathbf{9}}$ & 71.1 & 2.95 & 90 & 13.3 & 15 \\
$\mathbf{T}_{\mathbf{1 0}}$ & 7.4 & 3.15 & 90 & 0 & 05 \\
$\mathbf{T}_{\mathbf{1 1}}$ & 8.9 & 3.12 & 100 & 0 & 06 \\
$\mathbf{T}_{\mathbf{1 2}}$ & 5.9 & 3.07 & 100 & 0 & 05 \\
$\mathbf{T}_{\mathbf{1 3}}$ & 12.7 & 3.05 & 70 & 0 & 06 \\
$\mathbf{T}_{\mathbf{1 4}}$ & 5.1 & 3.04 & 100 & 0 & 05 \\
$\mathbf{T}_{\mathbf{1 5}}$ & 9.8 & 3.01 & 88 & 0 & 04 \\
\hline
\end{tabular}

Note: ' 0 ' indicate that vase life completed before senescence stage. 


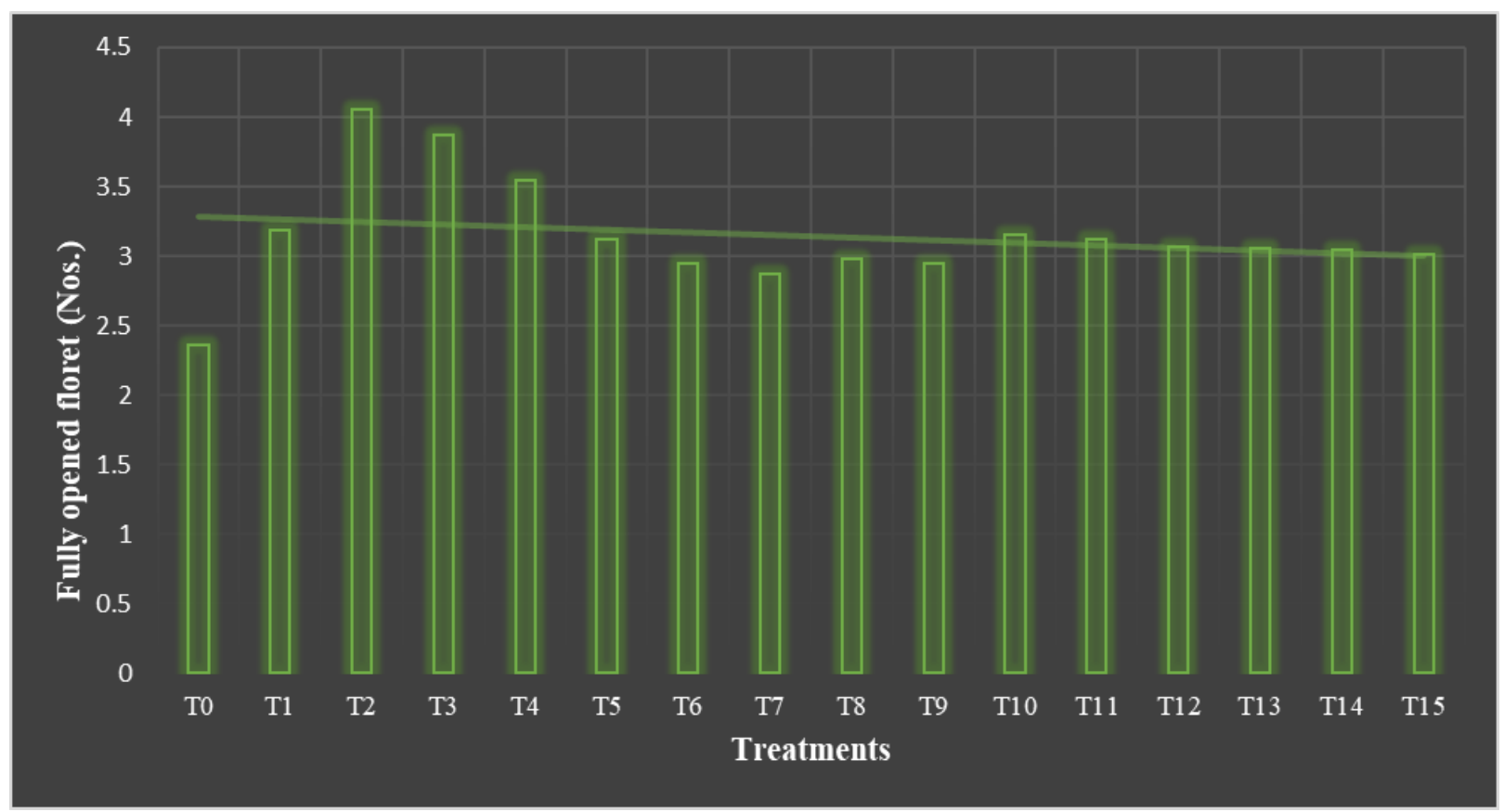

Fig 1. Number of fully opened florets per spike

Similar trends for results for spike length were also observed by Rana et al. (2005) in gladiolus spike. Pawar et al. (2018) also reported that salicylic acid $150 \mathrm{ppm}$ recorded significantly maximum length of spike.

\section{Spike vase life (day)}

Data presented in Table 1 showed that all the used materials led to extend the spikes vase life, compared with combination of SA and sucrose with ajowan essential oil, which causes vase life retardation. Also, sulfosalicylic acid (SA) at $150 \mathrm{ppm}$ with $5 \%$ sucrose treatment gave the longest vase life period of gladiolus cut spike. This treatment led to increase the spike vase life with $35.7 \%$ over the SA and sucrose with ajowan essential oil treatment. These results were probably due to the role of salicylic acid is an endogenous growth regulator of phenolic nature, which participates in the regulation of physiological processes in plants. SA can prevent ACC-oxidase and extend the vase life of cut flowers by decreasing reactive oxygen species (ROS) and ethylene (Zamani et al. 2011). This will have profound effects on the regulation of development process including flower senescence, consequently, the period of inflorescence duration could be increased. Similar trend of results was found by Liao et al. (2012) on Lilium plants, Ahmad and Dole (2014) on Zinnia plants and Sellam et al. (2016) on sweet sultan flowers.

\section{Fresh weight change (g)}

Data presented in Table 2 showed that using salicylic acid at $150 \mathrm{ppm}$ with $5 \%$ sucrose vase solution gave higher change in fresh weight $(\mathrm{g})$ at senescence stage compared with the control treatment, which led to increase the fresh weight $(\mathrm{g})$ with $38.9 \%$ over the control treatment. This improved water status of the spikes retained the fresh weight long (Tuna et al., 2007). In addition water stress and microorganisms that grow in vase solution affect duration of cut flowers (Bidarigh, 2015). Essential oil have antimicrobial property which reduce the amount of microorganism and keep cut flower fresh and ultimately extending vase life of cut flowers (Bayat et al., 2013). In gladiolus use of ajowan oil at $500 \mathrm{ppm}$ concentration give beneficial result on fresh weight and vase life of cut flowers (Marandi et al., 2011). It is also reported that thymol is major component in ajowan oil which is responsible against antibacterial property and give positive result by reducing proliferation in the stem vessels of cut gladiolus flowers (Marandi, 2011). During observation vase life of spikes were found end before the senescence stage in the treatment $\mathrm{T}_{10}, \mathrm{~T}_{11}, \mathrm{~T}_{12}, \mathrm{~T}_{13}, \mathrm{~T}_{14}$ and $\mathrm{T}_{15}$. It was also observed in during the study that all the spikes were bend after the treatment $\mathrm{T} 9$ during the investigation. After treatment $\mathrm{T} 9$, all the treatments showed maximum vase life around 4 to 6 days only. 
Table 2.Effect of different chemicals on change in the Fresh weight (F.W.) of spike

\begin{tabular}{|c|c|c|c|c|c|c|c|}
\hline \multirow[b]{3}{*}{ Sr. No. } & \multirow{3}{*}{$\begin{array}{c}\text { Fresh } \\
\text { weight } \\
\text { (g) }\end{array}$} & \multicolumn{6}{|c|}{ Change in Fresh weight w.r.t. Initial weight of spike } \\
\hline & & \multicolumn{2}{|c|}{$1^{\text {st }}$ day } & \multicolumn{2}{|c|}{$6^{\text {th }}$ day } & \multicolumn{2}{|c|}{ Senescence stage } \\
\hline & & $\begin{array}{c}\text { Absolute } \\
\text { weight (g) }\end{array}$ & $\begin{array}{c}\text { Change in } \\
\text { Fresh } \\
\text { weight (g) }\end{array}$ & $\begin{array}{c}\text { Absolute } \\
\text { Weight (g) }\end{array}$ & $\begin{array}{c}\text { Change in } \\
\text { Fresh } \\
\text { weight (g) }\end{array}$ & $\begin{array}{c}\text { Absolute } \\
\text { Weight (g) }\end{array}$ & $\begin{array}{c}\text { Change in } \\
\text { Fresh } \\
\text { weight (g) }\end{array}$ \\
\hline $\mathbf{T}_{\mathbf{0}}$ & 23.0 & 22.7 & -0.3 & 30.33 & 7.33 & 10.33 & -12.67 \\
\hline $\mathbf{T}_{1}$ & 29.0 & 31.7 & 2.7 & 36.67 & 7.67 & 26.33 & -2.67 \\
\hline $\mathbf{T}_{2}$ & 30.7 & 30.9 & 0.2 & 45.00 & 14.3 & 39.83 & 9.13 \\
\hline $\mathbf{T}_{3}$ & 25.0 & 25.5 & 0.5 & 38.33 & 13.33 & 32.00 & 7.0 \\
\hline $\mathbf{T}_{4}$ & 30.7 & 28.2 & -2.5 & 45.00 & 14.3 & 35.00 & 4.3 \\
\hline $\mathbf{T}_{5}$ & 27.0 & 27.7 & 0.7 & 41.67 & 14.67 & 26.00 & -1.0 \\
\hline $\mathbf{T}_{6}$ & 30.3 & 30.1 & -0.2 & 43.00 & 12.7 & 28.33 & -1.97 \\
\hline $\mathbf{T}_{7}$ & 26.7 & 27.2 & 0.5 & 40.00 & 13.3 & 31.33 & 4.63 \\
\hline $\mathbf{T}_{8}$ & 25.7 & 29.6 & 3.9 & 40.67 & 14.97 & 17.00 & -8.7 \\
\hline $\mathbf{T}_{9}$ & 32.7 & 36.6 & 3.9 & 48.00 & 15.3 & 38.50 & -12.67 \\
\hline $\mathbf{T}_{10}$ & 28.0 & 29.0 & 1.0 & 32.00 & 4.0 & 0 & 0 \\
\hline $\mathbf{T}_{11}$ & 32.0 & 32.3 & 0.3 & 36.00 & 4.0 & 0 & 0 \\
\hline $\mathbf{T}_{12}$ & 32.0 & 31.7 & -0.3 & 34.67 & 2.67 & 0 & 0 \\
\hline $\mathbf{T}_{13}$ & 27.7 & 26.6 & -1.1 & 29.67 & 1.97 & 0 & 0 \\
\hline $\mathbf{T}_{14}$ & 33.0 & 31.1 & -1.9 & 34.33 & 1.33 & 0 & 0 \\
\hline $\mathbf{T}_{15}$ & 28.0 & 30.7 & 2.7 & 30.67 & 2.67 & 0 & 0 \\
\hline S.Em. \pm & 0.43 & 0.47 & - & 0.51 & - & 0.19 & - \\
\hline C.D. at $5 \%$ & 1.32 & 1.35 & - & 1.37 & - & 0.85 & - \\
\hline
\end{tabular}

Note: ' 0 ' indicate that vase life completed before this stage.

: '-' indicate that loss in weight with respect to (w.r.t.) Fresh weight.

The possible region behind the bending of all the spikes may be that higher concentration of essential oils with salicylic acid damage the cut flower of Gladiolus by blockage the vascular systems due to less transpiration rate and more water absorption. Furthermore, the combination of these essential oils with other floral preservatives diminished the overall quality of the cut flower by injury to flower stem which may lead to bending the stem of cut gladiolus flower (Mirdehghan and Aghamolayi, 2016).

\section{Basal Floret diameter (cm) and longevity of florets}

Data presented in Table 3 showed that using salicylic acid at $150 \mathrm{ppm}$ with $5 \%$ sucrose vase solution gave the biggest diameter of basal floret with maximum longevity of gladiolus plant, compared with the other treatments. The said treatment led to increase the basal florets diameter with $10.1 \%$ over the control treatment. These results may be probably due to the role of salicylic acid at a proper concentration in plants. Salicylic acid increases chlorophyll content in the leaves along with boric acid (Raffeii and Pakkish, 2014), delay the senescence of flowers (Serrano et al., 2001) and it can act in regulation of metabolism processes such as protein synthesis, transport of sugar and carbohydrate metabolism (Abd-Elmotty and Fawzy, 2005), accordingly, the net assimilation rate in gladiolus cut spikes would be increased, thus the flower quality could be improved. Similar trend of results was reported by Mohammadi et al. (2014) on Gladiolus and Asgari and Moghadam (2015) on gerbera flowers. 
Table 3. Effect of different chemicals on diameter and longevity of basal floret

\begin{tabular}{cccccc}
\hline Sr. No. & $\begin{array}{c}\text { Diameter of } \\
\text { basal floret } \\
\text { at 0 day }(\mathbf{c m})\end{array}$ & \multicolumn{3}{c}{ Diameter of basal floret $(\mathbf{c m})$} & $\begin{array}{c}\text { Longevity of } \\
\text { Floret } \\
\text { (day) }\end{array}$ \\
\cline { 3 - 5 } & 2.05 & 2.21 & 2.97 & 3.53 & 1.97 \\
$\mathbf{T}_{\mathbf{0}}$ & 2.23 & 2.78 & 4.01 & 6.28 & 2.95 \\
$\mathbf{T}_{\mathbf{1}}$ & 2.25 & 2.95 & 4.18 & 7.13 & 5.13 \\
$\mathbf{T}_{\mathbf{2}}$ & 2.13 & 2.60 & 3.83 & 7.02 & 5.05 \\
$\mathbf{T}_{\mathbf{3}}$ & 2.06 & 2.55 & 3.78 & 6.85 & 5.01 \\
$\mathbf{T}_{\mathbf{4}}$ & 2.20 & 2.48 & 3.71 & 5.36 & 4.01 \\
$\mathbf{T}_{\mathbf{5}}$ & 2.15 & 2.62 & 3.85 & 5.52 & 4.06 \\
$\mathbf{T}_{\mathbf{6}}$ & 2.10 & 2.66 & 3.89 & 5.54 & 2.38 \\
$\mathbf{T}_{\mathbf{7}}$ & 2.08 & 2.36 & 3.59 & 6.24 & 3.01 \\
$\mathbf{T}_{\mathbf{8}}$ & 2.04 & 2.28 & 3.51 & 6.16 & 3.95 \\
$\mathbf{T}_{\mathbf{9}}$ & 2.14 & 2.68 & 3.91 & 5.56 & 2.08 \\
$\mathbf{T}_{\mathbf{1 0}}$ & 2.05 & 2.56 & 3.79 & 5.64 & 3.04 \\
$\mathbf{T}_{\mathbf{1 1}}$ & 2.17 & 2.62 & 3.85 & 5.50 & 3.05 \\
$\mathbf{T}_{\mathbf{1 2}}$ & 2.02 & 2.18 & 2.84 & 3.28 & 3.99 \\
$\mathbf{T}_{\mathbf{1 3}}$ & 2.11 & 2.42 & 3.62 & 4.96 & 2.07 \\
$\mathbf{T}_{\mathbf{1 4}}$ & 2.13 & 2.35 & 3.42 & 4.90 & 2.98 \\
$\mathbf{T}_{\mathbf{1 5}}$ & $\mathbf{0 . 1 5}$ & $\mathbf{0 . 1 7}$ & $\mathbf{0 . 1 8}$ & $\mathbf{0 . 2 1}$ & $\mathbf{0 . 2 1}$ \\
\hline S.Em. $\mathbf{\pm}$ & $\mathbf{0 . 4 1}$ & $\mathbf{0 . 4 2}$ & $\mathbf{0 . 4 4}$ & $\mathbf{0 . 4 7}$ & $\mathbf{0 . 6 1}$ \\
C.D. at $\mathbf{5}$ \% & & & &
\end{tabular}

\section{REFERENCES}

Abd-Elmotty, Z.E., and M. F. Fawzy. 2005. Response of Zebda and Langora mango trees to some bio- fertilization treatments. J. Agric. Sci. Mansoura Univ. 30(6). 33313341 .

Ahmad, I. and J. M. Dole. 2014. Homemade floral preservatives affect postharvest performance of selected specialty cut flowers. Hort Technology. 24(3):384-393.

Ahmad, I., J. M. Dole, A. S. Carlson and F.A. Blazich, 2013a. Water quality effects on postharvest performance of cut calla, hydrangea and snapdragon. Sci. Hort. 153:26-33.

Alaey, M., M. Babalar., R. Naderi and M. Kafi. 2011. Effect of pre- and postharvest salicylic acid treatment on physiochemical attributes in relation to vase-life of rose cut flowers. Postharvest Biology and Technology. 61(1):91- 94.

Asgari, M., and A. L. Moghadam. 2015. Comparison of different salicylic acid application ways as a preservative on postharvest life of gerbera cut flowers. Agricultural Communications. 3(4):1-8.

Bayat, H., R. Geimadil and A. A. Saadabad. 2013. Treatment with essential oils extends the vase life of cut flowers of lisianthus (Eustoma grandiflorum). Journal Medicinal Plants By-production. 2: 163-169.

Bidarigh, S. (2015). Improvement vase life of Chrysanthemum (Dendranthema grandiflorum L.) cut flowers using essential oils of Geranium, Eucalyptus and Myrtus. J Ornamental Plants. 4:213-221.

Brecheisen, S., H. P. Haas and R. Rober. 1995. Influence of water quality and chemical compounds on vase life of cut roses. Acta Hort. 405:392-400.
Burt, S. 2004. Essential oils: their antibacterial properties and potential applications in foods. Int. J. Food Microbiol. 94: 223-253.

Cameron, A.C. and M. S. Reid. 2001. 1-MCP blocks ethylene induced petal abscission of Pelargonium peltatum but the effect is transient. Post. Biol. Technol. 22:169-177.

Da Silva, J. T. 2003. The cut flower: postharvest considerations. Biol. Sci. 3:406-42.

Dantuluri, V. S. R., R. L. Misra and V. P. Singh. 2008. Effect of polyamines on post-harvest life of gladiolus spikes. Journal of Ornamental Horticulture. 11(1):66-68.

Dumitras, A., V. Lazar, D. Zaharia and M. Cantor, M. 2002. Influence of some domestic preserving solutions on the vase life time of some flower species. Buletinul Universitatii de Stiinte Agricole si Medicina Veterinaria Cluj Napoca Seria Hort. 57:142-145

El- Mokadem, H. S. 1991. Effect of some chemicals on the keeping quality of cut flowers of Strelitzia reginae banks.M.Sc. Thesis Alex University.

Ezhilmathi, K., V. P. Singh., A. Arora and R. K. Sairam. 2007. Effect of 5-sulfosalicylic acid on antioxidant activity in relation to vase life of Gladiolus cut flowers. Plant Growth Regulation. 51(2):99-108.

Gomez, K. A. and A. A. Gomez. 1984. Statistical procedures for agricultural research ( $2^{\text {nd }}$ Edition). John wiley and sons, New York, pp. 680.

Grant, M. and C. Lamb. 2006. Systemic immunity. Current Opinion in Plant Biology. 9:414-420. 
Hajizadeh, H. S. and A. A. Aliloo. 2014. Postharvest quality studies in tuberose (Polianthes tuberosa cv. Peril) cut flower as affected by vase preservative solutions. International Journal of Agriculture Innovations and Research. 2(6):895-899.

Hassan, F. A. S. and E. F. Ali. 2014. Protective effects of 1methylcyclopropene and salicylic acid on senescence regulation of gladiolus cut spikes. Scientia Horticulture. 179: 146-152.

Hatamzadeh, A, M., M. Hatami and M. Ghasemnezhad. 2012. Efficiency of salicylic acid delay petal senescence and extended quality of cut spikes of Gladiolu grandiflorus cv 'Wing's Sensation'. African Journal of Agricultural Research. 7(4): 540-545.

Khattab M., M. El-Torky and H. R. Abd-El-Hamid Torabeih. 2017. Effect of Some Chemicals on Vase Life of Gladiolus Cut Flowers. Alexandria Science Exchange Journal. 38(3):588-598.

Kuiper, D., S. Ribot, H. S. Van Reenen and N. Marissen. 1995. The effect of sucrose on the flower bud ripening of 'Madelon'cut roses. Sci. Hort. 60:325-336.

Liao, W. B., Z. M. Ling., H. G. Bao and Y. J. Hua. 2012. Hydrogen peroxide in the vase solution increases vase life and keeping quality of cut Oriental x Trumpet hybrid lily 'Manissa'. Scientia Horticulture. 139:32-38.

Loutfy, N., M. A. El-Tayeb, A. M. Hassanen, M. F. M. Moustafa, Y. Sakuma and M. Inouhe. 2012. Changes in the water status and osmotic solute contents in response to drought and salicylic acid treatments in four different cultivars of wheat (Triticum aestivum). J. Plant Res. 125:173-184.

Mackay, W. A., N. Sankhla., D. Sankhla and T. D. Davis. 2000. Postharvest performance of Lupinus havardii Wats., a new cut flower crop. Lupine, an ancient crop for the new millennium: Proceedings of the $9^{\text {th }}$ International lupine Conference, Klink/Muritz, Germany. :330-332.

Marandi, R. J., A. Hassani, A. Abdollahi and S. Hanafi. 2011. Improvement of the vase life of cut gladiolus flowers by essential oils, salicylic acid and silver thiosulfate. J .Medicinal plants Research. 5(20):503 -5043.

Mayak, S., B. Bradvo, A. Gvilli and A. H. Halevy. 1973. Improvement of opening of cut gladioli flowers by pretreatment with high sugar concentrations. Sci. Hortic. 1:357-365.

Mirdehghan, S. H., and Z. Aghamdayi. 2016. Application of various concentration of essential oil of Ajowansawory and thyme to maintain quality and shelf life of gladiolus cut flower. Int. J. Hortic. Sci. technol. 3(1):33- 41.

Miura, K., J. Lee, T. Miura and P.M. Hasegawa. 2010. SIZ1 controls cell growth and plant development in arabidopsis through salicylic acid. Plant Cell Physiology. 51:103-113.

Mohammadi, G. A., A. S. Sardoei and M. Shahdadneghad. 2014. Improvement of the vase life of cut gladiolus flowers by salicylic acid and Putrescine. International Journal of Advanced Biological and Biomedical Research. 2(2):417-426.
Nasibi, F., H. Farahmand., A. Kamyab and S. Alipour. 2014. Effects of arginine, cysteine and 5-sulfosalicylic acid on of vase life of tuberose cut flowers. Agricultural Communications. 2(2):35-41.

Pawar, A., Neha Chopde and Bhavishya Nikam. 2018. Effect of thiourea and salicylic acid on growth, flowering and yield of gladiolus. International Journal of Chemical Studies. 6(4): 2104-2106.

Peng, X.L., R. J. Ping and Z. Y. Long. 2007. Effect of exogenous salicylic acid on vase life of cut flowers of Prato lily and related physiological influence. [Chinese]. Acta Horticulture Sinica. 34(1):189-192.

Prabha, S., Sonal Sharma and Neha Khardia. 2018. Effects of essential oil on vase life of cut flowers: a review. University Research Resource Journal. 1(2):79-85.

Puneet, K. and D. Mukherjee. 2015. L-serine and spermine delay petal senescence in cut flowers of Calendula officinalis L. Lifesciences Leaflet. 69:112-124.

Raffeii, S. and Z. Pakkish. 2014. Effect of boric acid spray on growth and development of "Camarosa" strawberry (Fragaria x Ananassa Duck.) International journal of advanced Biological and Biomedical Research. 2(4):1060-1063.

Rana, P., J. Kumar and M. Kumar. 2005. Response of GA3 on plant spacing and planting depth on growth, flowering and corm production in gladiolus. Journal of Ornamental Horticulture. 8(1):41- 44.

Rao, I.V. and H. M. Ram. 1982. Specificity of Gibberellin and Sucrose-promoted flower bud growth in Gladiolus. Ann Bot 50(4): 473:479.

Rasul, J. M., A. Hassani., A. Abdollahi and S. Hanafi. 2011. Improvement of the vase life of cut gladiolus flowers by essential oils, salicylic acid and silver thiosulfate. J. Medic. Plants Research. 5(20): 5039-5043.

Sardoei, A. S., A. M. Gholam and R. Parviz. 2013. Interaction effect of salicylic acid and putrescine on vase life of cut narcissus flowers. Intr. J. Adv. Biol Biome Res .1(12):1569-1576.

Sellam, P., B. Singh., P. Rai and J. Majumder.2016. Potential of field grown sweet sultan (Centaurea moschata) as cut flower based on vase life. Indian Journal of agricultural sciences. 86(4):465-470.

Senaratna, T., D. Touchell., E. Bunn and K. Dixon. 2000. Acetyl salicylic acid (Aspirin) and salicylic acid induce multiple stress tolerance in bean and tomato plant. Plant Growth Regulation. 30:157-161.

Serek M., E. Sisler and M. Reid. 1994. Novel gaseous ethylene binding inhibitor prevents ethylene effects in potted flowering plants. J. Am. Soc. Hort. Sci.119:12301233.

Serrano, M., A. Amoros, M. T. Pretel, M. C. Martinez Madred and F. Romojaro. 2001. Preservative solutions containing boric acid delay senescence of carnation flowers. Postharvest Biology and Technology. 23:133- 142. 
Soobedar, Y., P. N. Kumar., A. Arora and R. Kumar.2015. Effect of protease inhibitors on physiological and biochemical changes influencing keeping quality in gladiolus. Indian Journal of Horticulture. 72(1):92-99.

Tian, J., X. Ban, H. Zeng, J. He, B. Huang and Y. Wang. 2011. Chemical composition and antifungal activity of essential oil from Cicutavirosa L. var. latisecta Celak. International Journal of Food Microbiology. 145:464470.

Tuna, A. L., C. Kaya, M. Dikilitas, I. Yokas, B. Burun and H. Altunlu. 2007. Comparative effects of various salicylic acid derivatives on key growth parameters and some enzyme activities in salinity stressed maize (Zea mays L.) Plants. Pak. J. Bot. 30(3):787-798.
Yamane, K., T. Kawauchi, Y. T. Yamaki and N. Fujishige. 2005. Effects of treatment with trehalose and sucrose on sugar contents, ion leakage and senescence of florets in cut gladiolus spikes. Acta. Hort. 669:351-358.

Yusuf, M., H. Shamul, M. N., Alyemeni, F. Qazi and A. Aqil. 2013. Salicylic acid: physiological Roles in plants'. ISBN: 974-94-007-6427-9 page 1:16.

Zamani, S., M. Kazemi and M. Aran. 2011. Postharvest life of cut rose flowers as affected by salicylic acid and glutamine. World Applied Sciences Journal. 12(9):16211624.

Zencirkiran, M. 2010. Effect of 1-MCP (1-Methyl Cyclopropene) and STS (Silver thiosulphate) on the Vase Life of Cut Freesia Flowers. Sci. Res. Essay. 5(17):24092412 . 